\title{
The Effect of Project Based Learning Model in the Group Investigation in Learning Strategy on Social Attitude Student Subject in USI Pematangsiantar
}

\author{
Fenny Mustika Piliang ${ }^{1}$, Asnewastri ${ }^{2}$ \\ ${ }^{1}$ Lecturer in Biology Study Program, Universitas Simalungun, Indonesia \\ ${ }^{2}$ Lecturer in History Education Study Program, Universitas Simalungun, Indonesia \\ feny.mustika88@gmail.com
}

\begin{abstract}
This study analyzes the determine the effect of project based learning model in the Group Investigation and conventional of learning strategy on social attitude student subject in USI Pematangsiantar. Samples are taken by total sampling, namely all semester VI students. The total sample of 60 people are grouped into the experimental group with the project based learning model in the Group Investigation, the experimental group with the Group Investigation learning model, and the control group with the conventional learning model. The research instrument was in the form of an observation sheet on students' social attitudes. This research method is quasiexperimental with data analysis techniques using ANOVA test at a significant level $\alpha=5 \%$ with the help of the SPSS 21.0 program. The result of this study found that: Social attitudes of students who are taught with project-based learning in the order of Group Investigation $83.10 \pm 4.52$ are significantly higher compared to Group Investigation learning $69.80 \pm 4.56$ and conventional learning $63.15 \pm 8,20$ with $\left(F_{\text {count }}=57.005 ; P=\right.$ 0.000). Thus, it can be concluded that the project based learning model in the Group Investigation order influences the social attitudes of USI Pematangsiantar students.
\end{abstract}

Keywords

project based leaming, group investigation; social attitude

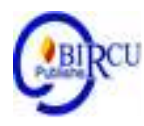

\section{Introduction}

Teaching and learning activities are complex conditions that are intentionally created (Dimyati and Mudjiono 2006). A teacher must be able to create effective learning conditions which contain various elements that influence one another. Samatowa (2010) states that "learning models suitable for Indonesian children are learning through direct experience (learning by doing)". The lecturer has given more lectures and exercises to do the questions quickly without giving a deep understanding of the concept.

With the dominant role of the lecturer as a source of knowledge, it does not foster good social attitudes among students. This is marked by the passivity of students when the learning process takes place. Then we need a learning that can lead students to develop social attitudes. Therefore we need a strategy that can really provide an answer to this problem. Any learning strategy that meets these criteria is project based learning in the order of Group Investigation.

Project based learning is supported by constructivist learning theory. Constructivism is a learning theory that has broad support that relies on the idea that students build their knowledge in the context of their own experiences. 
Mahanal's research results (2009), in students of SMAN 2 Malang stated that Project Based Learning (PjBL) proved to be effective in improving attitudes and learning outcomes so it was recommended to be applied by teachers in learning Biology. PjBl assists students in learning solid knowledge and skills that are built through authentic assignments and work. Learning outcomes are the level of mastery achieved by students in learning in accordance with the objectives set.

Learning that can help students to have creativity in thinking, solving problems, and interacting as well as helping in learning that leads to solving real problems is Project Based Learning $(\mathrm{PjBL})$ or project-based learning that is innovated in continuous learning towards Education for Sustainable Development (ESD) where Project-based learning can lead to real problems, stimulate motivation, process, and improve student achievement students of the faculty of culture in English Language Education study programs at UB Malang by using problems that are related to certain lectures in real situations. (Abd Syakur, 2017). According to Sardiman and Rahardjo in (Mansur, 2015), learning outcomes are mastery processes to measure student success agreed upon by the education provider. There are two factors that affect learning outcomes, namely (1) individual factors include maturity, intelligence, motivation, and personal factors; (2) social factors include teacher, family, and learning media. Learning outcomes must show better conditions, so it is useful to (1) increase knowledge, (2) increase understanding, (3) increase skills, (4) have a new outlook, and (5) appreciate something more.

The project-based learning model has the following characteristics: a) Students make decisions about a framework, b) Problems or challenges are presented to students, c) Students design processes to determine solutions to problems or challenges that are proposed, d) Students are collaboratively responsible for accessing and managing information to solve problems, e) The evaluation process is carried out continuously, f) Students periodically reflect on activities that have been carried out, g) The final product of learning activities will be evaluated qualitatively, h) The learning situation is very tolerant of mistakes and change (Muchsin, 2020).

(Kemendikbud, 2014). The above opinion, it can be concluded that the project-based learning model has the characteristics of the existence of problems or challenges raised to students, provide a more interesting and meaningful learning experience for students, produce tangible products, and the evaluation process is carried out continuously. Global issues that are sustainable in the industrial era 4.0, which requires universities to take part in the current Process, Input, Output and Outcome, one that is suitable for sustaining this project-based continuous learning is the educational approach which focuses on creative thinking, problem solving, and interaction between students and peers to create and use knowledge in the current digital era.

Syakur (2020) found the treatment of the TOEFL test, namely the pre-test and post-test in the control class and the experimental class in the Project Based Learning (PjBL) learning model there were differences. The average pretest toefl score in the experimental class was 344.71 with a range of values ranging from 300-397 and a standard deviation of 29.386. The average post-test toefl score in the experimental class, which is 360.83 with a range of values ranging from 303- 400 and a standard deviation of 24.146. Project Based Learning (PjBL) based learning can improve student learning outcomes, the p-value on PjBL is 0.026.

Munawaroh (2012), in his research on regular VIII grade students of SMP N 1 Tambakromo in the 2011/2012 Academic Year, stated that the Project Based Learning and cooperative models could be applied to build the four pillars of learning. Student learning 
outcomes taught by the Project Based Learning model are higher than the cooperative learning model.

In the project based learning process basically contains cooperative learning. Cooperative learning is a learning model that focuses on using small groups of students to work together in maximizing learning conditions to achieve learning goals that emphasize positive interdependence among students, individual responsibility, face-to-face, intensive communication between students, and evaluation of group processes (Slavin , 2010). Appropriate cooperative learning to be integrated with project-based learning on animal material and its environment is cooperative learning Group Investigation (GI).

The results of Eliawati's research (2011), in class X MAN Gandekan Bantul in the Academic Year 2010/2011, suggested that the application of the Group Investigation cooperative learning model was effective in increasing student participation and learning achievement in the subject matter mushroom class X MAN Gandekan Bantul in the Academic Year 2010/2011.

Based on observations of two instructional lecturers teaching learning strategies, the instructor lecturers often use the lecture, assignment and presentation methods in the learning process that takes place. Supporting lecturers are less creative in making variations of learning in accordance with the material being taught. This has an impact on students' social attitudes that cannot develop properly. This is marked by the passivity of students when the learning process takes place and there is no visible social interaction between fellow students, which in turn affects the low learning outcomes they obtain based on data collection of student grades. From these data the average student's score was 65.92 (Source: list of participants in the final exam of the learning strategies of USI Pematangsiantar students in the even semester T 201. 2018/2019). Based on the problems found by researchers at USI Pematangsiantar, the researchers chose to conduct research at the University.

Referring to the problem of learning in lecturing learning strategies experienced by students of Simalungun Pematangsiantar University, project based learning in the Group Investigation learning structure is indeed important and can overcome the problem of low social attitudes of students. For this reason, it is necessary to conduct research on the effect of the project based learning model in the Group Investigation learning structure on learning strategy on social attitude student subject in USI Pematangsiantar

\section{Research Methods}

This research was carried out in the Biology Education Study Program FKIP Universitas Simalungun, Jalan Sisingamangaraja Barat 1, Bah Kapul, Siantar Martoba District, Pematangsiantar in December 2019 to March 2020.

The sample in this study was taken in total sampling, that is all 60 semester students of Biology Education Study Program, Universitas Simalungun with a total of 60 people consisting of three classes, with the details of the experimental group being taught with a project-based learning model in the Group Investigation order namely Class IIIA, amounting to 20 people, an experimental group that was taught with a Group Investigation learning model, namely class IIIB, amounting to 20 people, and a control group that was taught with a conventional learning model, namely class IIIC, amounting to 20 people.

The research will be carried out using quasi-experimental methods. The research design that will be used is nonequivalent control group design or non randomized control pretest postest design, meaning that the experimental group and the control group were not randomly selected. 
To meet the validity requirements of the data obtained through this research, internal and external validity controls are carried out. The research instrument used for collecting research data was an observation sheet.

The instrument used in this study consisted of treatment instruments and data collection instruments.

This study used data analysis techniques in the form of descriptive analysis and inferential analysis. Descriptive analysis is intended to describe the research data including the mean, median, standard deviation and trend data. Inferential statistical analysis is carried out to test the research hypothesis, which is firstly carried out a prerequisite test of the data collected using normality and homogeneity tests.

Inferential data analysis technique was used to test the research hypothesis using the ANOVA test at a significant level $\alpha=5 \%$ then continued with the Post-Hoc Test (further test) with the Tukey technique. Further tests were conducted to find out which variables had significant differences. To test the normality of the data used the Kolmogorof-Smirnov test at a significance level of $5 \%$. Homogeneity test for data variance using Levene Test at a significant level of 5\%. Data were analyzed using SPSS 21.0 software.

\section{Discussion}

\subsection{Result}

From the research that has been done, it is obtained data about social attitudes in the classroom taught by project based learning in the order of Group Investigation after being conducted for 4 meetings the highest score is 94 and the lowest score is 76 with an average score and standard deviation $(83.10 \pm 4,52)$ and the data are normally distributed $(Z=0.87$; $\mathrm{P}=0.42$ ). In the Group Investigation class, obtained the highest score of students' social attitudes of 77 and the lowest of 59 with an average value and standard deviation of (69.80 \pm 4.56) and data with normal distribution $(\mathrm{Z}=1.03 ; \mathrm{P}=0.23)$. While in the conventional class, observation data obtained by social attitudes of students with the highest score of 72 and lowest 48 with an average value and standard deviation of $(63.15 \pm 8.20)$ and data with normal distribution $(\mathrm{Z}=0.63 ; \mathrm{P}=0,75)$. The description of students' social attitudes can be seen in table 1.

Table 1. Description of Student Social Attitudes

\begin{tabular}{lrrr}
\hline \multirow{2}{*}{ Statistics } & \multicolumn{3}{c}{ Observation of Social Attitudes } \\
\cline { 2 - 4 } & PJBL_GI & GI & KONV \\
\hline Mean & 83,10 & 69,80 & 63,11 \\
Std. Deviation & 4,53 & 4,56 & 8,20 \\
Max Score & 94,00 & 77,00 & 72,00 \\
Min Score & 76,00 & 59,00 & 48,00 \\
\hline
\end{tabular}

Based on the results of the hypothesis test, it was found that the social attitudes of students who were taught with a project-based learning model in the Group Investigation order obtained Fcount $>$ Ftable, namely 57.005 $>4.98$ and a probability value of $0.000<0.001$, indicating that the learning model significantly affected the social attitudes of students. Furthermore, Tukey's test results show that the social attitudes of students who are taught with project-based learning in the order of Group Investigation $(83.10 \pm 4.52)$ are significantly higher than the social attitudes of students who are taught with the Group Investigation learning model without PjBL $(69.80 \pm 4,56)$ or those taught with conventional learning $(63.15 \pm 8,20)$. The effect of the project-based learning model in the Group 
Investigation (GI) order on the social attitudes of USI Pematangsiantar students is presented in Figure 1.

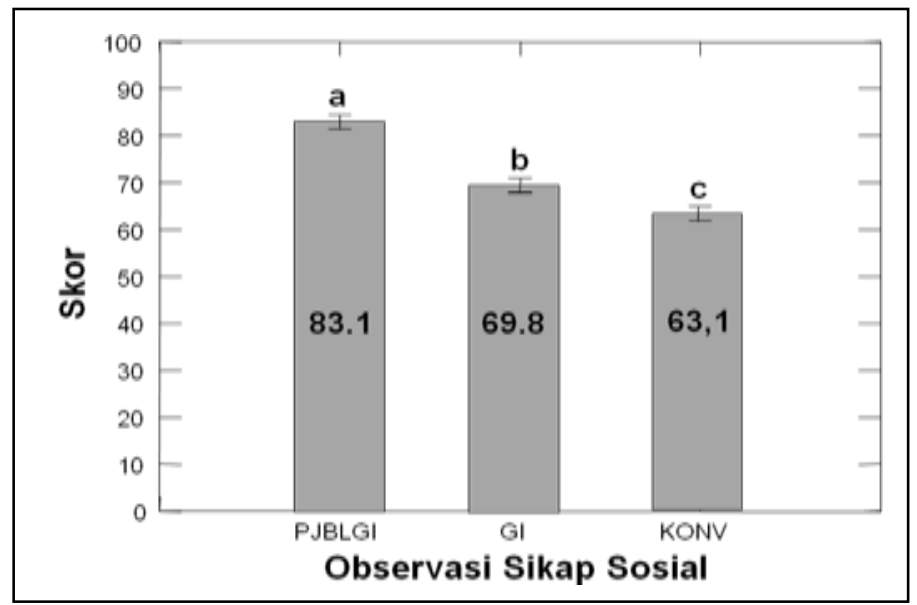

Figure 1. Effect of project-based learning models in the order of Group Investigation, Group Investigation learning, and conventional learning on Learning Strategy on Social Attitude

Student in USI Pematangsiantar $(\mathrm{F}=57.005 ; \mathrm{P}=0,000)$. Different letters above the diagram mean significantly different (Tukey test).

\subsection{Discussion}

In the results of this study it was found that the social attitudes of students who were taught with the project-based learning model in the order of Group Investigation gave an effect of $19 \%$ higher compared to Group Investigation learning without project-based learning and $31 \%$ higher compared to conventional learning. The Group Investigation learning model gives an effect of $10 \%$ higher than conventional learning. Based on the results of the analysis of research data obtained Fcount> Ftable thus HO is rejected and $\mathrm{Ha}$ is accepted so that it is concluded that there is a significant influence between the use of projectbased learning models in the order of Group Investigation, Group Investigation learning, and conventional learning in learning strategy on social attitude student subject in USI Pematangsiantar.

This shows that the project-based learning model in the Group Investigation order is proven to be effective in improving students' social attitudes. This is because in the project based learning model in the order of Group Investigation students are required to be able to plan, investigate, work on projects, to present the results of their projects in learning strategy courses that discuss animals and their environment. Where in each of these stages a good social attitude is established among fellow students.

According to Ibrahim (2001), social attitude is an appreciation of the social value of individuals in a group as a result of communication between group members and an atmosphere of interdependence which is a necessity to guarantee human existence. To find out the success of a learning related to social attitudes, it is necessary to measure the learning. Measurement of social attitudes is by observation in the learning process takes place. According to Krech, Crutchfield and Ballachey (1982), in Ibrahim (2001), a person's social attitude appears in the pattern of responses between people expressed by interpersonal relationships in the ongoing process. Therefore we need instruments related to this matter. Observation assessment of students' social attitudes was carried out by observers using rubric scores 1,2,3 and 4 as well as yes and no statements. Students who are taught using the 
project-based learning model in the Group Investigation learning arrangement for social attitude assessment more often score 4 and yes. While students who are taught with Group Investigation learning more often get a score of 2 and 3 and the statement yes.

Thus, based on the results of research, statistical testing and existing theories it is evident that the group of students who are taught with a project-based learning model in the Group Investigation order gives a better influence in stimulating and growing social attitudes of students because basically learning requires students to can collaborate with groups in giving opinions, accepting friends' opinions, being disciplined and responsible for their duties. While groups of students who are taught with conventional learning, the learning process tends to be centered on lecturers using the lecture method. During the learning process, students' social attitudes do not develop, because students learn more individually by receiving, taking notes, and memorizing the subject matter they receive from the lecturer as a determinant of the learning process.

\section{Conclusion}

Based on the results and discussion of the research described in the previous chapter, it can be concluded as follows: There is a significant influence on the social attitudes of students who are taught by project based learning in the order of Group Investigation and conventional learning in learning strategy on social attitude student subject in USI Pematangsiantar 2019 Academic Year / 2020. A better and more influential learning model is the project-based learning model in the Group Investigation order.

\section{References}

Abd Syakur. (2017). Education For Sustainable Development (ESD) Sebagai Respon Dari Isu Tantangan Global Melalui Pendidikan Berkarakter Dan Berwawasan Lingkungan Yang Diterapkan Pada Sekolah Dasar, Sekolah Menengah Dan Kejuruan Di Kota Malang. 1(1), 37-47.

Dimyati \& Mudjiono (2006). Belajar dan Pembelajaran. Jakarta: Rineka Cipta.

Eliawati (2011). Efektifitas Penerapan Model Pembelajaran Kooperatif Tipe STAD Terhadap Partisipasi dan Prestasi Belajar pada Materi Pokok Jamur Siswa Kelas X di MAN Gandekan Bantul Tahun Ajaran 2010 /2011. Skripsi. Yogyakarta: Universitas Islam Negeri Sunan Kalijaga.

Ibrahim, R (2001). Pembinaan Perilaku Sosial Melalui Pendidikan Jasmani. Jakarta: Direktorat Jendral Olahraga.

Kemendikbud. 2014. Peraturan Menteri Pendidikan dan Kebudayaan, tentang Implementasi Kurikulum Pedoman Umum Pembelajaran. Nomor 81A, Tahun 2013.

Mahanal, S., Darmawan, E., Corebima, A.D., Zubaidah, S (2009). Pengaruh Pembelajaran Project Based Learning (PjBL) pada Materi Ekosistem Terhadap Sikap dan Hasil Belajar Siswa SMAN 2 Malang. Universitas Negeri Malang.

Mansur, N. (2015). Pencapaian Hasil Belajar Ditinjau Dari Sikap Belajar Mahasiswa Nurdin Mansur Fakultas Tarbiyah dan keguruan UIN Ar-Raniry Banda Aceh. 3(2).

Muchsin. Mariati. (2020). Application of Project Based Learning Models in Improving Creative Thinking of Students at Physics Lessons in SMA Bandar Baru. Budapest International Research and Critics Institute-Journal (BIRCI-Journal), 1453-1458

Munawaroh, R., Subali. \& Sopyan (2012). Penerapan Model Project Based Learning dan Kooperatif untuk Membangun Empat Pilar Pembelajarn Siswa SMP. Unnes Physics Education Journal (UPEJ). 1 (1): 33-37. 
Samatowa, U (2010). Bagaimana Pembelajaran IPA di Sekolah Dasar. Jakarta: Depdiknas. Slavin, R.E (2010). Cooperative Learning. Bandung: Nusa Media.

Syakur et al. (2020). The Effect of Project Based Learning (PjBL) Continuing Learning Innovation on Learning Outcomes of English in Higher Education. Budapest International Research and Critics in Linguistics and Education (BirLE) Journal, 625630. 